\section{THE INTERNATIONAL HEALTH AND EDUCATION EXHIBITION}

THERE is at first sight some lack of unity of purpose in an exhibition which undertakes to illustrate such diverse subjects as health and public education. This impression will be in the present case confirmed partly by the postponement of the opening of the Educational Section to the month of June, and partly by the fact that the display of educational appliances will be held in the neighbouring building, the new Technical School of the City and Guilds of London Institute, and not in the galleries of the Exhibition building itself. A mere miscellaneous collection of objects more or less illustrative of school work, e.g. furniture, fittings, apparatus, and diagrams, would, however, prove of little general interest and value, unless it were on a very comprehensive scale. The Executive Committee, therefore, have wisely decided to limit the scope of the educational part of the Exhibition of the present year, and to direct the attention of exhibitors mainly to the elucidation of a few special problems which possess exceptional importance or public interest at the present time. Foremost among these are the subjects of technical and scientific instruction, trade and apprenticeship schools, the teaching of art, and the Kindergarten with other devices for infant training. The accidental association of this part of the Exhibition with one devoted to the subject of health has also naturally suggested another class of illustrative display likely to prove particularly interesting to school managers and the public at this moment. While the Executive Committee has shown no disposition to encourage the absurdly exaggerated and not very sincere outcry which has been raised about the "over-pressure" of children in schools, they have shown much judgment in giving special prominence to those "exhibits" which are designed to illustrate the conditions of healthy life in schools. Accordingly, models of the best school buildings, appliances for warming, lighting, and ventilating, improved desks and fittings, contrivances for sccuring right posture for the limbs and for preventing injury to eyesight, precautions against disease in schools, will be largely shown. The whole subject of physical training will also, it is expected, be illustrated with unusual fullness and variety. Models and examples of the latest and best forms of gymnastic apparatus in use in England and in foreign countries will be shown; and arrangements are being made, with the sanction of the heads of the Admiralty and of the War Office, for the practical exposition of the methods of military drill in use in the great military and naval schools at Chelsea and Greenwich, on certain afternoons on which the boys can be spared for this purpose from their ordinary school duties.

The increased attention now being directed to the whole subject of infant training; the extended interest taken by the best teachers in the study of the methods of Fröbel; and the recognition by the Education Department for the first time, in Mr. Mundella's Code, of the need of training, object lessons, recreation, and varied employment in infant schools, as well as instruction in reading, writing, and arithmetic, have justified the appropriation of a considerable space to the Kindergarten, and to the exhibition of pictures, games, manual exercises, and apparatus specially adapted for the training of very young children, whether in schools or nurseries. There is reason to believe that this department of the display will be especially full and interesting, and will comprise some of the latest and most ingenious of the devices for infant discipline which are in use in Germany and Switzerland, as well as in our own country.

Closely connected also with the general design of the Exhibition to show how school-life may be made healthier, brighter, happier, and more interesting, there will be a considerable display of pictures and school de- corations. The "Art for Schools Association" and other exhibitors will seek to show how the school-room may be incidentally useful in improving the taste and stimulating the imagination of the scholars; and it may be hoped that many teachers will gather from the Exhibition some fruitful suggestions as to the manner in which art may give added reality and force to lessons on history, on descriptive geography, on the facts of science, and on the life of the ancient world.

The London, Birmingham, and other School Boards have arranged for collective displays of their best fittings, desks, and other apparatus. Illustrations and models of school kitchens, cookery schools, and the latest appliances for the practical teaching of domestic economy will be tolerably numerous; and special pains have been taken by those members of the Education Committee who have recently served on the Technical Instruction Commission to procure some of the most characteristic illustrations of the methods of technical and industrial teaching in use in the trade and apprentice schools of the Continent.

There will be a library and reading room attached to the educational department of the Exhibition; and a large collection of the newest text-books, treatises, diagrams, and works of reference having relation to the subject of the Exhibition will be so arranged that they may easily be consulted by visitors.

One very interesting feature of the whole programme will be found in the plan-not yet fully matured - for an International Congress or series of Conferences to be held in connection with the Exhibition during the first week in August. A large attendance of delegates from foreign countries is expected, and some of the most important educational problems of the day will be discussed. The sub-Committee, which has spent much time in arranging the details, is representative in its character, and consists of Lord Reay, the Hon. L. Stanley, two of the Senior Inspectors of Schools, Mr. Sharpe and Mr. J. G. Fitch, Archdeacon Emery, the Rev. Dr. Graham of the Hammersmith Training College, Mr. Storr, Mr. Magnus, Mr. St. John Ackers, and Dr. Rigg. So far as the arrangements have yet been published, they promise to provide a series of valuable public discussions, by persons of authority in their special departments, on the organisation of primary, secondary, and university education; on the conditions of health and physical development in schools ; on the professional training of teachers, the testing of their qualifications, and the public recognition of those qualifications; on several special departments of instruction, $e . g$. infant training, art teaching, science and technical teaching; and on museums, libraries, and other subsidiary agencies by which the influence of the school may be extended to the home life, to leisure, and to the means of self-improvement.

\section{NOTES}

THн, Council of the Royal Society have selected the following fifteen candiclates to be recommended for clcction at the annual meeting on June I2 next:--Prof. George Johnston Allman, LL.D., Prof. Isaac Bayley Balfour, D.Sc., Joseph Baxendell, F.R.A.S., James Bell, F.I.C., Prof. Walter Noel Hartley, F.R.S.E., Prof. Alexander Stewart Herschel, M.A., Wilfrid II. Hudleston, M.A., Prof. Horace Lamb, M.A., Prof. John G. McKendrick, M.D., Arthur Ransome, M.D., Prof. Charles Smart Roy, M.D., Prof. Arthur William Ruicker, M.A., Joseph John Thomson, B.A., Licut.-Col. Charles Warren, C.M.G., and Prof. Morrison Watson, M.D.

THE following three savants were elected Foreign Members of the Linnean Society at the last meeting, May I :-Dr. Ernst Haeckel, Professor of Zoology and Director of the Zoological Institut, Museum, University of Jena, among other things well known for his studies of Sponges, Radiolarians, Medusæ, \&c. ; 